УДК 347.77.78:341.24

DOI https://doi.org/10.32849/2663-5313/2020.4.03

Ольга Волощенко,

канд. юрид.наук,

старший викладач кафедри цивільно-правових дисциплін

юридичного факультету

Харківського національного університету імені В. Н. Каразіна

\title{
НОВЕЛІЗАЦІЯ ЗАКОНОДАВСТВА ІНТЕЛЕКТУАЛЬНОЇ ВЛАСНОСТІ В УМОВАХ ЄВРОІНТЕГРАЦИЙНОЇ ПОЛІТИКИ УКРАЇНИ: ПРОБЛЕМИ ТЕОРІЇ І ПРАКТИКИ
}

У статті розглянуто законодавчі новели права інтелектуальної власності України в умовах євроінтеграційної політики України. Проаналізовано норми начіонального законодавства, міжнародних угод, пов'язаних з реалізачією прав на об'єкти інтелектуальної власності. Автором виявлено низку тенденцій, які сприяють удосконаленню правового регулювання географічного зазначення походження товарів і режиму захисту інших об'єктів інтелектуальної власності України. Констатовано, що основними чинниками удосконалення законодавства у сфері інтелектуальної власності є імплементація норм законодавства Європейського союзу й аналіз судової практики. Сформульовано окремі пропозииї шодо удосконалення иивільного законодавства у сфері реалізаиї̈ прав на географічне зазначення походження товару. Запропоновано внести зміни до Цивільного кодексу України щодо визначення критерї̈, які обмежують дію в часі виключних майнових прав на географічне зазначення. Автором визначено, що термін дії виключних майнових прав на географічне зазначення не є безстроковим. Підставою втрати виключних майнових прав на географічне зазначення походження товару варто вважати втрату особливих характеристик та якостей відповідної території походження товару. Виявлено термінологічні неточності у ст. 397 Митного кодексу Украӥни. Запропоновано видалити категорію «підозра» $і$ зазначити перелік критерїв, за наявності яких уповноважена особа матиме право належни чином реагувати на порушення виключних майнових прав законних правоволодільців. До переліку таких критерїв автор відносить: відсутність правовстановлюючих документів на право використання об'єкта інтелектуальної власності, наявність спільних ознак об'єктів, які перетинають кордон, з об'єктами, внесеними до митного реєстру. Серед основних перспектив удосконалення законодавства щодо права інтелектуальної власності автор пропонує продовжувати процедуру імплементації норм законодавства Європейського союзу. Позитивний досвід використання такого підходу у законотворчій діяльності держави вбачається у якості прийнятих законів і сприятиме максимально точно наблизити вітчизняне законодавство до стандартів нормотворчої діяльності Свропейського союзу.

Ключові слова: європейська інтеграція, імплементація норм Європейського союзу, географічне зазначення, захист об'єктів права інтелектуальної власності, митний контроль.

Постановка проблеми. Свроінтеграція, як пріоритетний напрям розвитку внутрішньої і зовнішньої політики України, не тільки надала спектр можливостей щодо вдосконалення вітчизняного законодавства, але і стала справжнім випробуванням «на міцність» для державних структур у питаннях якості впровадження політичних, соціальноекономічних, правових та інституційних реформ. Сфера права інтелектуальної власності як справжній headliner реформування внутрішніх процесів надала платформу для прийняття низки угод і нормативно-правових актів, серед яких: Закони України «Про державну підтримку кінематографії, «Про ефективне управління майновими правами правовласників у сфері авторського права i (або) суміжних прав», «Про внесення змін до деяких законодавчих актів України щодо вдосконалення правової охорони географічних зазначень», «Про внесення змін до Митного кодексу України щодо захисту прав інтелектуальної власності під час переміщення товарів через митний кордон України» тощо.

Прийняття ж у 2015 році Національної стратегії розвитку права інтелектуальної власності України на період до 2020 р. (далі - Стратегія) підтвердило позитивні наміри держави щодо потенційних 
кроків до гармонізації вітчизняного законодавства права інтелектуальної власності зі стандартами Свропейського Союзу. Разом із тим темпи і якість виконання поставлених завдань з моменту підписання Угоди про асоціацію між Україною та Європейським Союзом (далі - Угода) виправдовують існування того спектру проблем, які залишаються невирішеними у сьогоденні.

Аналіз останніх досліджень і публікацій дає змогу констатувати, що проблеми євроінтеграційних процесів у сфері інтелектуальної власності були предметом дослідження низки вчених цивілістів, серед яких - Ю. М. Капіца, Р. О. Стефанчук, О. В. Кохановська, Р. В. Шаповал, О. О. Штефан, Ю. В. Носік, О. С. Гирич та інші. Однак аналіз законотворчої діяльності держави дає змогу констатувати наявність низки проблем практичного характеру, серед яких: невиконання завдань, поставлених Стратегією; незавершеність процесу створення Спеціального суду з питань інтелектуальної власності як похідна проблема від першої; наявність прогалин у правовій регламентації колективного управління виключними майновими правами; патентний «тролінг»; обіг контрафактної продукції тощо.

Завдання статті зумовлені проблематикою даної теми, дала змогу окреслити подалыші напрями дослідження та передбачають розроблення найбільш дієвих механізмів з подолання наявних проблем. Основними цілями даного дослідження є: аналіз чинного законодавства щодо окремих об'єктів права інтелектуальної власності в аспекті його відповідності законодавству Свропейського союзу; виявлення причин наявності термінологічних невідповідностей у Митному кодексі України щодо режиму контролю піл час перетину кордону об'єктами права інтелектуальної власності.

Метою даного дослідження $є$ розробка та надання науково-практичних висновків i рекомендацій 3 питань удосконалення права інтелектуальної власності в умовах євроінтеграційної політики України.

Виклад основного матеріалу. 31 січня 2020 року набрали чинності Закон України «Про внесення змін до деяких законодавчих актів України щодо вдосконалення правової охорони географічних зазначень» [1] і Закон України «Про внесення змін до Митного кодексу України щодо захисту прав інтелектуальної власності під час переміщення товарів через митний кордон України» [2]. Такий результат нормотворчої діяльності $€$, безумовно, позитивним у контексті виконання зобов'язань, які Україна взяла на себе у зв'язку з підписанням Угоди.
Так, розширено перелік повноважень осіб, які можуть реалізувати свої виключні майнові права на географічне зазначення походження товарів, і можливості способів захисту виключних майнових прав таких осіб. Разом із тим аналіз чинних положень не виключає наявності певного роду неточностей у питаннях практичного застосування норм зазначених законів.

Прийняття Закону України «Про внесення змін до деяких законодавчих актів України щодо вдосконалення правової охорони географічних зазначень» надало якісно нове бачення правової охорони географічного зазначення. Зазначене твердження зумовлюється тим, що такий закон удосконалює правове регулювання відносин у сфері інтелектуальної власності шляхом імплементації у національне законодавство як положень Регламенту Свропейського союзу № 1151/2012 Європейського парламенту та ради Європейського союзу від 21 листопада 2012 року про якість сільськогосподарських продуктів та продуктів харчування, так і вимог статей 204-207 Угоди про асоціацію з Европейським Союзом [3].

Відтепер розширено поняття географічного зазначення, суб'єктний склад осіб, які можуть реалізувати свої права на використання зазначеного об'єкта, а також регламентовано підстави правової охорони для омонімічних географічних зазначень тощо.

У новій редакції статті 5 Закону України «Про охорону прав на зазначення походження товарів» законодавець надав можливість «іноземцям та іншим особам, що мають місце постійного проживання чи постійне місцезнаходження поза межами України, у відносинах з Установою реалізувати свої права шляхом безпосереднього звернення до Установи або через представників у справах інтелектуальної власності (патентних повірених)». [4]

Таке положення відповідає принципу національного режиму, який гарантується усім іноземцям і особам без громадянства на період перебування на території України. Разом із тим варто зазначити, що з наданого принципу є винятки, що стосуються, наприклад, заборони на використання права власності на земельну ділянку сільськогосподарського призначення.

Поняття географічного зазначення у контексті закону розуміється як найменування місця, що ідентифікує товар, який походить із певного географічного місця та має особливу якість, репутацію чи інші характеристики, зумовлені головним чином цим географічним місцем походження, 
і хоча б один з етапів виробництва якого (виготовлення (видобування) та/або переробка, та/або приготування) здійснюється на визначеній географічній території. Таким чином, головним критерієм надання правової охорони для найменування місця є наявність унікальних властивостей тієї території, яка вважається місцем походження товару, що ідентифікується. Звертаємо увагу, що географічне зазначення виконує не лише ідентифікаційну функцію, а в тому числі є інструментом підвищення цінності, авторитету, інтересу до держави, на території якої знаходиться місцевість походження того чи іншого продукту. Вищезазначене аргументує твердження про підвищену цінність географічного зазначення як об'єкта права інтелектуальної власності.

У рамках забезпечення і збереження унікальності такого об'єкта вважаємо за доцільне закріпити на законодавчому рівні виключну можливість реєстрації прав на географічне зазначення за громадянами України.

Попри позитивні новели, наявна велика кількість прогалин у регулюванні питання реалізації прав на географічне зазначення походження товарів. Відповідно до положень спеціального закону «Про охорону прав на зазначення походження товарів» правова охорона надається кваліфікованим зазначенням походження товарів на підставі їх реєстрації, яка діє безстроково від дати реєстрації [4]. Твердження стосовно початку дії прав на відповідний об'єкт є правильним і відповідає принципам реєстраційної системи набуття прав. Однак безстроковість дії таких прав викликає певні сумніви. Застосування категорії «безстроковість» не є доцільною у формулюванні зазначеної норми як відносно виключних майнових прав і не виправдовує себе у практичному значенні.

По-перше, дія прав на кваліфіковане географічне прямо пропорційно залежить від якісних характеристик території походження товару. Тому природне виснаження регіону походження призводить до анулювання відмінних і таких цінних природних якостей товару, що, своєю чергою, спричинить і втрату відповідних майнових прав на кваліфіковане географічне зазначення.

По-друге, момент припинення виключних прав може бути результатом вольового рішення правоволодільця. Закон не містить будь-яких обмежень стосовно припинення дії виключних майнових прав на зазначений об'єкт з власної ініціативи правоволодільця. Таким чином, допустимість припинення виключних майнових прав на кваліфіковане географічне зазначення за вольовою ознакою $є$ очевидною.
Враховуючи вищевикладене, пропонуємо викласти ч. 2 ст. 6 Закону України «Про охорону прав на зазначення походження товарів» у такій редакції: «Цим Законом надається правова охорона кваліфікованим зазначенням походження товарів на підставі їх реєстрації, яка діє до моменту втрати характеристик товару, позначеного цим зазначенням, або до моменту припинення прав з ініціативи законного правоволодільця».

В умовах євроінтеграційної політики найбільш ефективним способом наближення вітчизняного законодавства до європейських стандартів з точки зору якості нормативного матеріалу визначаємо імплементацію норм законодавства Європейського союзу. Зазначене положення підтверджується позитивним досвідом України у нормотворчому процесі. Так, Закон України «Про внесення змін до деяких законодавчих актів України щодо вдосконалення правової охорони географічних зазначень» закріпив якісно новий підхід до розуміння суб'єктного складу осіб, які мають право на реєстрацію прав на географічне зазначення. Аналіз змісту новел дає підстави вважати, що зазначений закон став справжнім осередком імплементованих норм Директив Свропейського союзу.

Згідно з положеннями оновленого законодавства щодо охорони географічних зазначень право на державну реєстрацію такого об'єкта має об'єднання осіб, які у певному географічному місці займаються виробництвом товару або здійснюють на відповідній території хоча б один етап із процесу виробництва, особлива якість, репутація чи інші характеристики якого зумовлені цим географічним місцем [1]. Поняття «об'єднання осіб» законодавець визначає як сукупність суб'єктів, які задіяні у виробництві товару, що ідентифікується географічним зазначенням, а також як один суб'єкт , якщо він відповідає двом критеріям:

1)є єдиним виробником у відповідному географічному місці;

2) географічна територія, на якій здійснюється виробництво або один і етапів виробництва, а також товар мають характеристики, які істотно відрізняються від прилеглих територій.

Новелізація у питанні визначення суб'єктного складу осіб, які мають право на реєстрацію географічного зазначення, $є$ прикладом процесу імплементації ст. 5(1) Регламенту Ради (ЄС) № 510/2006 від 20.03.2006 р. про захист географічних зазначень та зазначень походження сільськогосподарської продукції та продуктів харчування. Фактичне «перенесення» норм 3 європейського акта не тільки сприяло уточненню 
чинних вітчизняних норм, але і безпрецедентно вирішило питання гармонізації.

Абз. 2 ч. 1 статті 397 Митного кодексу України у новій редакції передбачає: «У разі підозри у порушенні прав інтелектуальної власності щодо товарів, митні формальності щодо яких здійснюються без подання митної декларації, органами доходів і зборів призупиняється виконання митних формальностей щодо таких товарів згідно з положеннями статей 399 або 400, або $401^{-1}$ цього Кодексу» [5]. Зазначена стаття наділяє представників митних органів повноваженнями превентивного характеру, які передбачають застосування до потенційних порушників виключних майнових прав на об'єкти права інтелектуальної власності заходів запобігання вчиненню правопорушення. Однак звертаємо увагу, що зазначена редакція статті містить певні ризики неналежного іï виконання як під впливом помилкового судження, так і внаслідок умисного вчинення дій шляхом використання службового становища.

Категорія «підозра» в Академічному тлумачному словнику визначається як «думка про чию-небудь причетність до чогось негативного, сумнів у чиїй-небудь порядності, чесності, відданості і т. ін.» [6, с. 475]. Виходячи із такого формулювання, законодавець зазначив можливість існування ситуації, коли застосування попереджувального заходу (згідно зі ст. 397 Митного кодексу України) може грунтуватися на особистій думці такої особи або групи осіб. Помилковість суджень осіб, які не є експертами у сфері права інтелектуальної власності, щодо можливості порушень прав законних право володільців є допустимою. Правильність такого твердження зумовлюється тим, що більшість об'єктів промислової власності повинні володіти певними критеріями, наявність або відсутність яких підтверджується висновком експертизи.

Як результат, помилка судження або умисні дії щодо підозри неправомірного використання об'єктів інтелектуальної власності може спричинити процес гальмування зовнішньоекономічної діяльності суб'єкта, маючи наслідком втрату прибутків у вигляді майнової шкоди, в тому числі і упущеної вигоди.

Отже, застосування такої термінологічної конструкції не є доцільним з точки зору об'єктивності та має певні недоліки практичного характеру в питаннях запобігання зловживанню службовим становищем осіб, які здійснюють митний контроль.

3 огляду на вищевикладене, пропонуємо замінити термін «підозра» на визначення критеріїв, за наявності яких уповноважена особа матиме право належним чином реагувати згідно зі ст. 397 Митного кодексу України. До переліку останніх варто віднести: відсутність правовстановлюючих документів на право використання об'єкта інтелектуальної власності, наявність спільних ознак об'єктів, які перетинають кордон, з об'єктами, внесеними до митного реєстру.

\section{Висновки}

Аналіз окремих аспектів новелізованого законодавства у сфері права інтелектуальної власності надав можливість констатувати наявність позитивних змін у правовому регулюванні режиму використання географічних зазначень. Імплементація норм законодавства Свропейського союзу як основний чинник удосконалення надала можливості максимального наближення до стандартів європейського рівня.

Під час теоретичного дослідження новинок законодавчої діяльності виявлено і низку неточностей. Зокрема, констатовано наявність термінологічної неточності у Митному кодексі України щодо вчинення запобіжних дій за умови наявності підозри про порушення прав інтелектуальної власності. Доктринальне узагальнення дозволило надати рекомендації щодо необхідності зазначення критеріїв визнання дій протиправними. До числа перших відносимо:

1) відсутність правовстановлюючих документів на право використання об'єкта інтелектуальної власності;

2) наявність спільних ознак об'єктів, які перетинають кордон, з об'єктами, внесеними до митного реєстру.

3-поміж питань правового регулювання порядку використання географічного зазначення доведено безпідставність безстроковості дії виключних майнових прав на такий об'єкт. Як спосіб подолання зазначеної проблеми запропоновано закріпити на законодавчому рівні обмежувальні обставини дії таких прав.

Загалом, доктринальний аналіз виявив позитивні тенденції у процесах новелізації законодавства сфери інтелектуальної власності. Однак констатована проблематика правового регулювання географічного зазначення, а також інших об'єктів доводить необхідність подальших досліджень у зазначеній сфері.

\section{Список використаних джерел:}

1. Про внесення змін до деяких законодавчих актів України щодо вдосконалення правової охорони географічних зазначень : Закон України від 20.09.2019 № 123-IX. URL : https:// zakon.rada.gov.ua/laws/show/123-20 (дата звернення: 28.03. 2020). 
2. Про внесення змін до Митного кодексу України щодо захисту прав інтелектуальної власності під час переміщення товарів через митний кордон України : Закон України від 17.10.2019 № 123-IX. URL : https://zakon.rada.gov.ua/laws/show/202-IX (дата звернення: 28.03. 2020).

3. Про асоціацію між Україною, з однієі сторони, та Європейським Союзом, Європейським співтовариством 3 атомної енергії і їхніми державами-членами, з іншої сторони : Угода від 30.11.2015 № 984. URL : https://
zakon.rada.gov.ua/laws/show/202-IX (дата звернення: 29.03.2020).

4. Про охорону прав на зазначення походження товарів : Закон України від 16.06.1999 № 752-XIV. URL : https://zakon.rada.gov.ua/laws/ show/752-14 (дата звернення: 29.03. 2020).

5. Митний кодекс України : Закон України від 13.03.2012 № 4495-VI. URL: https://zakon.rada.gov.ua/ laws/show/4495-17 (дата звернення: 28.03. 2020)

6. Словник української мови : в 11 т. Київ, 1975. T. $6.801 \mathrm{c}$.

The article deals with the legislative innovations of the intellectual property rights of Ukraine in the context of the European integration policy of Ukraine.National legislation, international agreements related to the realization of intellectual property rights are analyzed. The author has identified a number of trends that contribute to improving the legal regulation of the geographical indication of origin of goods and the regime of protection of other objects of intellectual property in Ukraine. It is noted that the main factors for improving the legislation in the field of intellectual property are the implementation of European Union legislation and the analysis of case law. Separate proposals have been formulated for the improvement of civil legislation in the field of the right to geographical indication of origin of goods. It is proposed to amend the Civil Code of Ukraine regarding the definition of criteria that restrict the exclusive right of ownership to geographical indications. The author has determined that the term of exclusive proprietary rights to geographical indications is limited in time The loss of exclusive rights to the geographical indications of origin of goods shall be considered the loss of special characteristics and qualities of the respective territory of origin of goods. The existence of terminological inaccuracies in Article 397 of the Customs Code of Ukraine is revealed. It is proposed to exclude the category of "suspicion" and to specify a list of criteria according to which the authorized person will have the right to respond appropriately to the infringement of the exclusive property rights of the legal owners. The following criteria were identified: lack of legal documents for the right to use the intellectual property object, the presence of common features of objects crossing the border with items entered in the customs register. Among the main prospects for improving legislation on intellectual property, the author proposes to continue the process of implementation of European Union legislation. Positive experience of using such approach in the legislative activity of the state is considered as adopted laws and will help to bring the domestic legislation as close as possible to the standards of the European Union.

Key words: European integration, implementation of the European Union rules, geographical indication, intellectual property rights protection, customs control. 